\title{
PERAN SERTA IBU MENGHINDARKAN KELUARGA DARI RESIKO PENYAKIT BAWAAN MAKANAN (FOODBORNE DISEASE)
}

\author{
Begum Fauziyah \\ Jurusan Kimia Fakultas Saintek UIN MALIKI Malang \\ Email : bee_fauzia@yahoo.co.id
}

\begin{abstract}
Recently, we often hear that government have announced about 2010 health indonesian programme. The aim of this programme is to create health indonesian people and good in quality human. One of the key to success this programme is fullfill food which save, health and permitted for indonesian people. Food is important needed for people to life. So, people must consume good and health food to make good quality human. Save, health and permitted food is food that did'nt contain or free from biological contaminant, chemical contaminant or materials that can loss and damage human health. The health interference that is caused by contaminant in food is called by foodborne disease. The indications of this disease are queasy, throw up, diarrhea, cramps in stomach and fever. Because of that, it needs control and analysis in each step of food chain. As we know, food chain contain of quality repairing step of food raw materials, control contaminant step in food technology and food preparation step to be consumed. All of those steps need to control and analysis of contaminant to make sure that food in good and health condition to be consumed. According to Nature theory, Functional theory and Islamic perspective, a housewife has duty to manage family needed especially cooking. Back to the food chain, a housewife has urgent role in the third step of food chain. It means, a housewife has urgent role to create health and good quality of family and save family from foodborne disease. Because of that, a housewife has to know about foodborne disease, hygiene procedure in food preparation process and saving food procedure.
\end{abstract}

Keywords : foodborne disease, contaminant, food chain, hygiene procedure. 


\section{PENDAHULUAN}

Sejak beberapa bulan terakhir, telah sering kita dengar dan kita ketahui bahwa pemerintah telah mencanangkan program Indonesia Sehat 2010. Pencanangan program ini bertujuan untuk mewujudkan bangsa Indonesia yang sehat dan terbebas dari berbagai penyakit sehingga tercipta sumber daya yang berkualitas. Salah satu kunci pokok keberhasilan tujuan dari program Indonesia Sehat 2010 adalah tercukupinya makanan yang aman, sehat, utuh dan halal atau yang dikenal dengan istilah ASUH, bagi masyarakat Indonesia (Bintoro et al., 2009).

Makanan merupakan kebutuhan dasar manusia yang bersifat hakiki sehingga harus senantiasa terpenuhi setiap saat. Menurut Bintoro (2009), makanan yang baik adalah yang layak dikonsumsi, aman, bermutu, bergizi dan harganya terjangkau. Keamanan makanan didefinisikan sebagai kondisi dan upaya yang diperlukan untuk mencegah makanan dari kemungkinan cemaran biologis, kimia dan bahan lain yang dapat mengganggu, merugikan dan membahayakan kesehatan manusia (Peraturan Pemerintah RI No. 28 Tahun 2004). Aman untuk dikonsumsi dapat diartikan bahwa produk makanan tidak mengandung bahan yang dapat membahayakan kesehatan atau keselamatan manusia yaitu menimbulkan penyakit atau keracunan (Bintoro, 2009). Penyakit-penyakit yang disebabkan dari makanan yang dikonsumsi disebut penyakit bawaan makanan atau foodborne disease. Gejala penyakit bawaan makanan antara lain mual, muntah, diare, sakit kepala, demam, menggigil, lemah, kejang perut dan lain-lain.

Penyakit bawaan makanan (foodborne disease), biasanya bersifat toksik maupun infeksius, disebabkan oleh agen penyakit yang masuk ke dalam tubuh melalui konsumsi makanan yang terkontaminasi. Kadang-kadang penyakit ini disebut "keracunan makanan" (food poisoning) walaupun istilah ini kurang tepat. Penyakit bawaan makanan mencakup lingkup penyakit yang etiologinya bersifat kimiawi maupun biologis, termasuk penyakit kolera dan diare, sekaligus beberapa penyakit parasit (Anonim 1, 2005).

Penyakit bawaan makanan merupakan salah satu permasalahan kesehatan masyarakat yang paling banyak dan paling membebani yang pernah dijumpai di zaman modern ini. Penyakit tersebut menyebabkan banyak korban dalam kehidupan manusia dan menyebabkan sejumlah besar penderitaan, khususnya di kalangan bayi, anak, lansia, dan mereka yang kekebalan tubuhnya terganggu.

Munculnya kontaminan penyebab penyakit bawaan makanan atau foodborne disease dapat terjadi dalam rantai proses pengolahan makanan, mulai dari sumber bahan mentah hingga penyajian makanan dalam keluarga. Proses tersebut terdiri dari tiga tahapan yaitu 
perbaikan mutu bahan mentah dalam pertanian, penerapan tekhnologi pangan yang dapat mengendalikan kontaminan dan tahap penyajian makanan atau konsumsi. Ketiga tahapan tersebut harus senantiasa dikontrol dan dianalisis kontaminasinya (Anonim 2, 2005).

Pada tahap penyajian makanan bagi konsumsi keluarga, ibu memiliki peranan penting sebagai penentu kesehatan dan kualitas sumber daya anggota keluarga. Namun, apakah selama ini kalangan ibu telah menjalankan peran tersebut dengan baik ?. Karena kontrol dan analisis kontaminan tidak mungkin dilakukan di tingkat rumah tangga, maka dibutuhkan solusi yang tepat untuk tetap dapat mewujudkan tujuan program Indonesia sehat 2010. Salah satunya dengan menerapkan pendidikan dan pelatihan bagi kalangan ibu tentang apa foodborne disease serta bagaimana gejala dan penyebabnya. Selain itu, ibu juga harus diperkenalkan tata cara personal hygiene dan pengelolaan serta penyimpanan makanan yang benar. Dengan informasi tersebut, diharapkan ibu dapat memerankan dengan baik fungsinya dalam menyediakan makanan bagi anggota keluarga dalam rumah tangga sehingga anggota keluarga dapat terhindar dari penyakit bawaan makanan atau foodborne disease. Hal ini menjadi penting mengingat asupan makanan yang baik sangat menentukan kualitas sumber daya manusia khususnya bagi keluarga dan umumnya bagi bangsa dan Negara.

\section{MAKANAN YANG HALAL DAN BAIK}

Didalam Peraturan Pemerintah RI No. 28 Tahun 2004 telah disebutkan bahwa keamanan makanan didefinisikan sebagai kondisi dan upaya yang diperlukan untuk mencegah makanan dari kemungkinan cemaran biologis, kimia dan bahan lain yang dapat mengganggu, merugikan dan membahayakan kesehatan manusia. Menurut Judarwanto (2009), pemberian asupan makanan yang baik harus dilihat dari berbagai aspek seperti aspek ekonomi, aspek sosial, aspek agama, aspek budaya dan aspek medik dari konsumen makanan itu sendiri. Makanan yang dikonsumsi sebaiknya memenuhi kriteria serasi, selaras dan seimbang. Serasi artinya sesuai dengan tingkat tumbuh kembang anggota keluarga. Selaras adalah sesuai dengan kondisi ekonomi, sosial, budaya serta agama yang dianut keluarga, sedangkan seimbang artinya nilai gizi harus sesuai dengan kebutuhan dan jenis makanan. Kriteria-kriteria tersebut tentunya harus didasarkan pada suatu standar tertentu yang telah disepakati bersama. Dengan terpenuhinya beberapa kriteria tersebut, harapan terciptanya suatu sumber daya manusia yang berkualitas akan dapat diwujudkan.

Allah SWT telah memberikan batasan terhadap makanan yang halal untuk dikonsumsi dan dimanfaatkan oleh manusia. Selain apa yang disebutkan haram oleh nash yang shahih dan tegas seperti darah, daging babi dan bangkai, Allah SWT menghalalkan yang lainnya. 
Dengan demikian wilayah haram dalam syariat islam sangat sempit sedangkan wilayah halal sangat luas. Namun demikian, Allah SWT telah memerintahkan dalam Al-qur'an, agar kaum muslimin hanya mengkonsumsi makanan yang halalan thoyyiban. Artinya, bukan hanya makanan yang halal hukumnya, melainkan juga baik bagi manusia. Perintah tersebut termaktub dalam surat an-nahl ayat 114 yang artinya :

"Maka makanlah yang halal lagi baik dari rezeki yang telah diberikan Allah kepadamu, dan syukurilah nikmat Allah, jika hanya kepada-Nya kamu menyembah (An-Nahl : 114)".

Ayat tersebut memerintahkan untuk memakan yang halal lagi baik karena tidak semua makanan yang halal otomatis baik. Hal ini dikarenakan hukum halal sesungguhnya terdiri dari 4 macam hukum yaitu, wajib, sunnah, mubah dan makruh. Selanjutnya tidak semua yang halal sesuai dengan kondisi masing-masing pribadi. Sebagai contoh, ada yang halal dan baik buat si A karena faktor kesehatan tertentu, namun kurang baik manfaatnya bagi si B (Shihab, 2002).

\section{PERAN SERTA IBU DALAM RANTAI PENGOLAHAN MAKANAN}

Rantai proses pengolahan makanan dimulai dari sumber bahan mentah hingga penyajian makanan. Dengan demikian, pada setiap tahapan proses dapat terjadi kontaminasi atau pencemaran terhadap bahan atau makanan.

Rantai makanan memiliki panjang dan kompleksitas yang bervariasi menurut derajat urbanisasi atau industrialisasinya. Tahapan rantai makanan tersebut ditunjukan pada gambar 1. Pencegahan penyakit bawaan makanan mensyaratkan dilakukannya pencegahan atau pengendalian terhadap kontaminasi pada segala tahap dalam rantai makanan mulai dari tahap produksi sampai konsumsi. Walaupun demikian, berbagai tindakan yang diterapakan pada tahap dini dalam rantai makanan hanya akan efektif jika tindakan tersebut juga diterapkan dalam tahap lanjut, khususnya jika makanan yang disiapkan ditujukan untuk konsumsi.

Strategi dalam pencegahan penyakit bawaan makanan dapat dijelaskan dalam pengertian tiga garis pertahanan. Perbaikan mutu bahan mentah dalam pertanian, penerapan tekhnologi pangan yang dapat mengendalikan kontaminan dan tahap penyajian makanan atau konsumsi. Pengalaman memperlihatkan bahwa kendati segala upaya sudah dilakukan dalam bidang pertanian pada tahap pertama, terkadang kontaminasi bahan pangan tidak dapat dihindari mengingat beberapa organisme merupakan flora alami yang hidup di lingkungan manusia. Toksin juga dapat terbentuk secara alami didalam makanan (Anonim 2, 2005). 


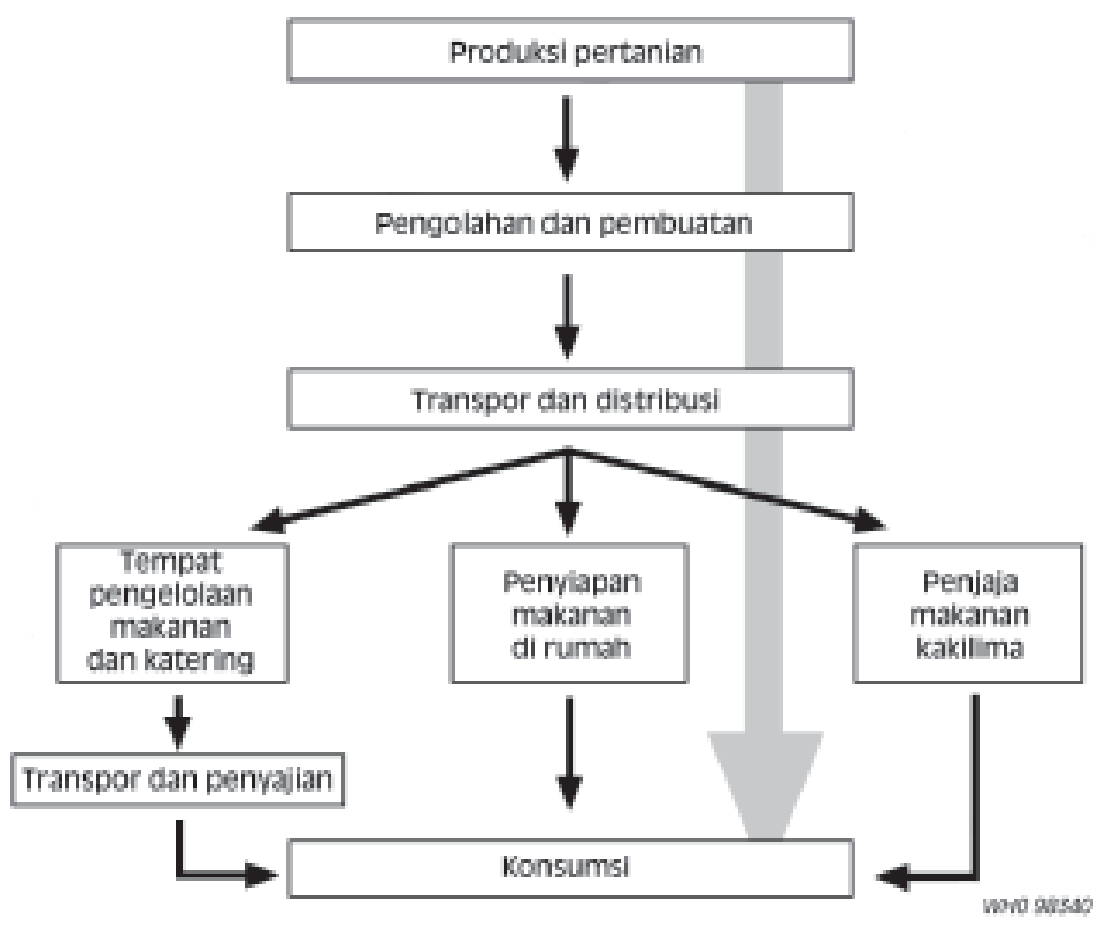

Gambar 1. Rantai Makanan

Garis pertahanan yang kedua yaitu penerapan teknologi pengolahan makanan untuk menghilangkan atau mengurangi patogen atau kontaminan, dengan sendirinya belum cukup untuk menjamin keamanan. Sebab makanan dapat terkontaminasi kembali setelah diolah khususnya selama penyiapannya oleh pengelola makanan yang mungkin menjadi carrier patogen penyakit.

Dengan demikian, garis pertahanan yang ketiga yaitu penyiapan makanan di rumah merupakan tahapan penentu dalam menjaga keamanan makanan. Tahap ini merupakan unsur yang sangat menentukan di dalam mencegah penyakit bawaan makanan sekalipun tahap pertama dan kedua gagal. Pengelola makanan yang bertugas untuk menyiapkan makanan harus dibekali pendidikan dan pelatihan mengenai tata cara pengolahan makanan yang aman dan sehat serta tata cara penyimpanan makanan yang benar agar terhindar dari kontaminan penyebab penyakit bawaan makanan (Anonim 2, 2005).

Keamanan makanan berarti bahwa pada saat dikonsumsi makanan tidak mengandung kontaminan dalam kadar yang membahayakan kesehatan. Semua orang baik yang menyiapkan ataupun konsumen merupakan bagian dari rantai makanan. Sebagai bagian dari rantai makanan tersebut, maka mereka berarti ikut bertanggung jawab bersama pemerintah dan industri makanan dalam menjamin keamanan makanan. Konsep tanggung jawab bersama ini dilukiskan dalam Gambar 2. 


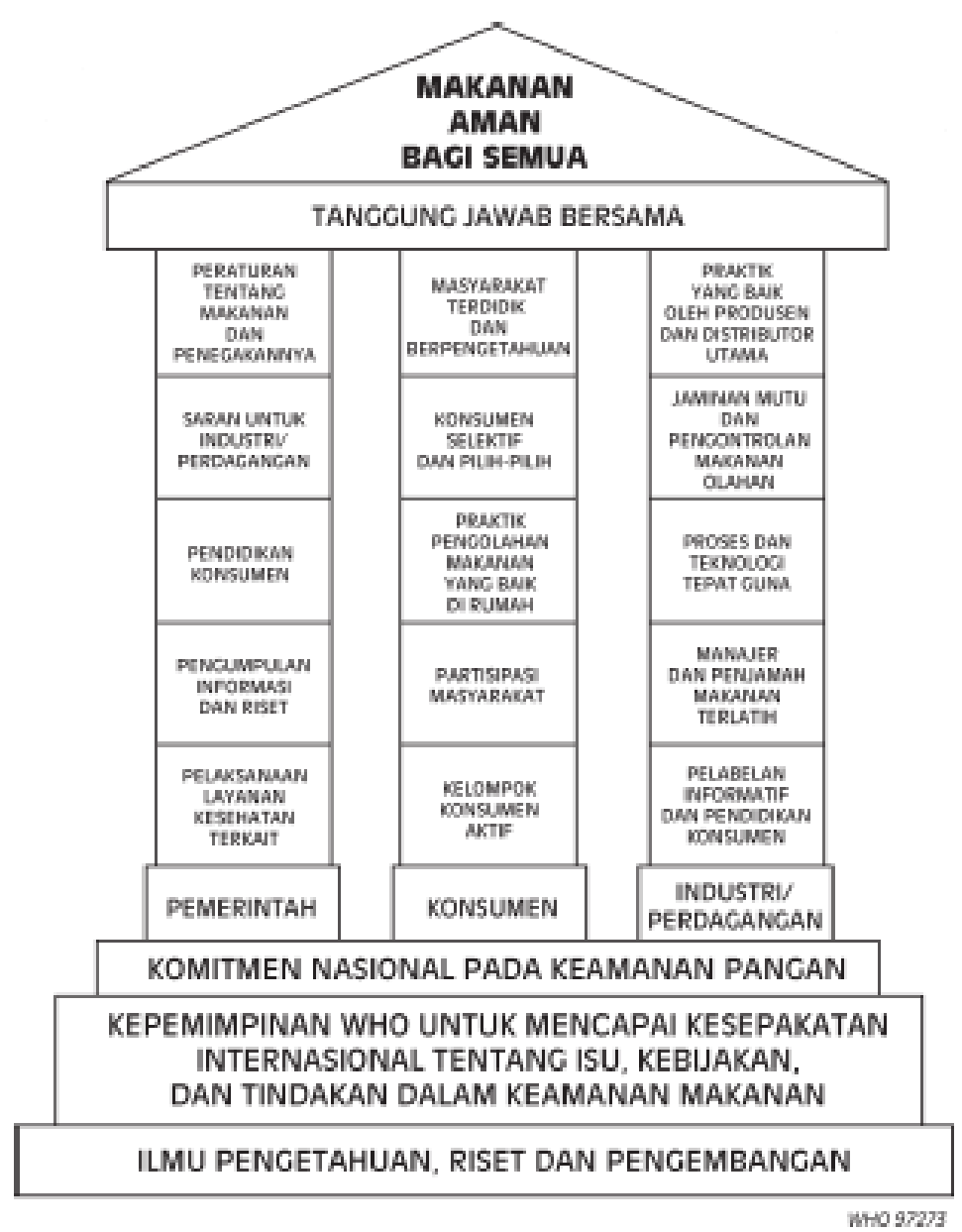

Gambar 2. Konsep Tanggung Jawab Bersama

Dalam penyediaan makanan yang aman, sehat, utuh dan halal serta makanan yang memenuhi kriteria kualitas yang baik dalam suatu keluarga, peranan ibu sangatlah vital. Rasulullah SAW, sebagaimana telah diriwayatkan oleh Bukhari dan Muslim, telah bersabda :

"Seorang laki-laki adalah pemimpin keluarganya dan kelak akan dimintai pertanggungjawabannya terhadap mereka. Seorang wanita adalah pemimpin bagi rumah suami dan bagi anak-anaknya dan ia akan dimintai pertanggungjawabannya terhadap apa yang dipimpinnya (HR. Bukhari-Muslim)".

Menurut teori Nature (Muassomah, 2009), peran wanita dalam suatu keluarga adalah mengurus rumah tangga, melahirkan dan membesarkan anak-anaknya, mengurus keperluan suami, membersihkan rumah dan memasak. Tidak berbeda dengan teori Nature, teori Fungsional juga berpandangan bahwa wanita harus tinggal di dalam rumah. Karena hal ini merupakan pembagian yang paling baik dan berguna bagi keuntungan masyarakat secara keseluruhan. Talcot Parsons juga menyatakan bahwa pekerjaan wanita adalah mengerjakan pekerjaan-pekerjaan rumah tangga. 
Dalam rantai proses pengolahan makanan pada gambar 1 dan 2, ibu menempati posisi pada tahap akhir atau tahap penentu yaitu tahap penyiapan makanan. Tahap ini merupakan unsur yang sangat menentukan di dalam mencegah penyakit bawaan makanan. Dengan kata lain, ibu sangat menentukan asupan bagi sumber daya manusia dalam keluarga, yang pada akhirnya sangat menentukan kualitas anggota keluarga.

Akan tetapi, kontrol yang resmi seperti analisis kontaminan sangat tidak mungkin diterapkan dalam tingkat rumah tangga. Dengan demikian, cara utama untuk mengendalikan keamanan makanan yang dibuat dirumah adalah dengan memberikan pendidikan bagi pengelola makanan mengenai cara-cara penanganan makanan yang aman. Dengan kata lain, pengendalian atau kontrol harus dilakukan oleh pengelola makanan itu sendiri dan untuk tujuan ini, para pengelola makanan harus dilatih atau dididik dengan benar.

Berdasarkan hal itu, seorang ibu harus membekali dirinya dengan pengetahuan dan pendidikan mengenai penyakit bawaan makanan, baik itu definisi gejala dan penyebabnya. Selain itu, seharusnya seorang ibu mengetahui prosedur personal hygiene sebagai seorang pengelola makanan. Hal ini disebabkan kemungkinan manusia berperan sebagai vector pembawa kuman sangat tinggi. Penyimpanan makanan juga sangat menentukan tumbuh tidaknya faktor penyebab penyakit bawaan makanan. Oleh sebab itu, pendidikan atau pelatihan mengenai tata cara pengelolaan bahan makanan dan penyimpanan makanan sangat penting bagi seorang ibu.

\section{PENGERTIAN FOODBORNE DISEASE DAN PENYEBABNYA}

Foodborne disease atau penyakit bawaan makanan adalah penyakit yang dihantarkan melalui makanan atau sering disebut penyakit akibat konsumsi makanan atau minuman yang telah terkontaminasi. Kontaminan dapat berupa kuman, virus atau racun dalam makanan yang ada secara alamiah atau sengaja dicampurkan (NSW Multicultural Health Communication Service, 2004). Contoh kuman penyebab kontaminasi adalah Salmonella, Campylobacter dan Listeria. Contoh virus penyebab kontaminasi adalah Norovirus dan contoh racun adalah racun yang dibuat oleh kuman Staphylococcus Aureus atau Bacillus Cereus. Selain kontaminan tersebut, bahan pencemar yang mungkin terdapat dalam makanan adalah bahan kimia seperti pestisida, insektisida dan bahan pengawet serta bahan pencemar fisik seperti rambut dan kerikil.

Kontaminan yang paling sering menyebabkan masalah kesehatan adalah bakteri. Bakteri adalah mikroba kecil yang tak tampak oleh mata telanjang yang dapat menyebabkan infeksi yang bersifat akut ataupun kronis. Bakteri ini dapat hidup bila terdapat sumber 
makanannya misal protein, suhu yang sesuai untuk pertumbuhannya yaitu sekitar $4-60\left({ }^{\circ} \mathrm{C}\right)$ dengan kelembaban dan kandungan air yang tinggi. Bakteri dapat berkembang cepat dan mencapai jutaan hanya dalam tempo 3-4 jam. Bakteri juga dapat mengeluarkan toksin atau racun yang menimbulkan penyakit. Toksin tersebut dapat bertahan lama walaupun bakterinya telah mati. Bahkan beberapa toksin dapat bertahan di suhu tinggi (Anonim 3, Tanpa tahun).

Selain penyakit bawaan yang bersifat infeksi, juga terdapat penyakit bawaan yang bersifat alergi dan intoksikasi. Alergi adalah kondisi dimana tubuh menolak zat atau kandungan yang ada dalam makanan sedangkan intoksikasi adalah masuknya racun ke dalam tubuh baik karena adanya toksin biologi ataupun toksin kimiawi.

Mikroba atau racun pertama kali masuk ke dalam tubuh melalui saluran pencernaan menyebabkan gejala awal sebagian besar foodborne disease adalah mual, muntah, diare, sakit kepala, demam, menggigil, lemah, kejang perut dan lain-lain. Foodborne disease yang paling sering terjadi antara lain yang disebabkan oleh bakteri Campylobacter, Salmonella, dan E. coli dan oleh golongan virus calicivirus, yang juga sering disebut sebagai Norwalk virus. Selain itu ada pula yang disebabkan oleh parasit seperti sistiserkus (Damayanti, 2008).

Penyakit bawaan makanan kerapkali dipandang sebagai penyakit yang ringan dan dapat sembuh dengan sendirinya. Akan tetapi, pada banyak kasus yang terjadi justru serius dan bahkan dapat mengakibatkan kematian. Konsekuensi kesehatan akibat penyakit bawaan makanan bervariasi menurut patogen penyebabnya, tahapan dan lamanya pengobatan juga dengan usia dan faktor lain yang yang berkaitan dengan daya tahan dan kerentanan seseorang.

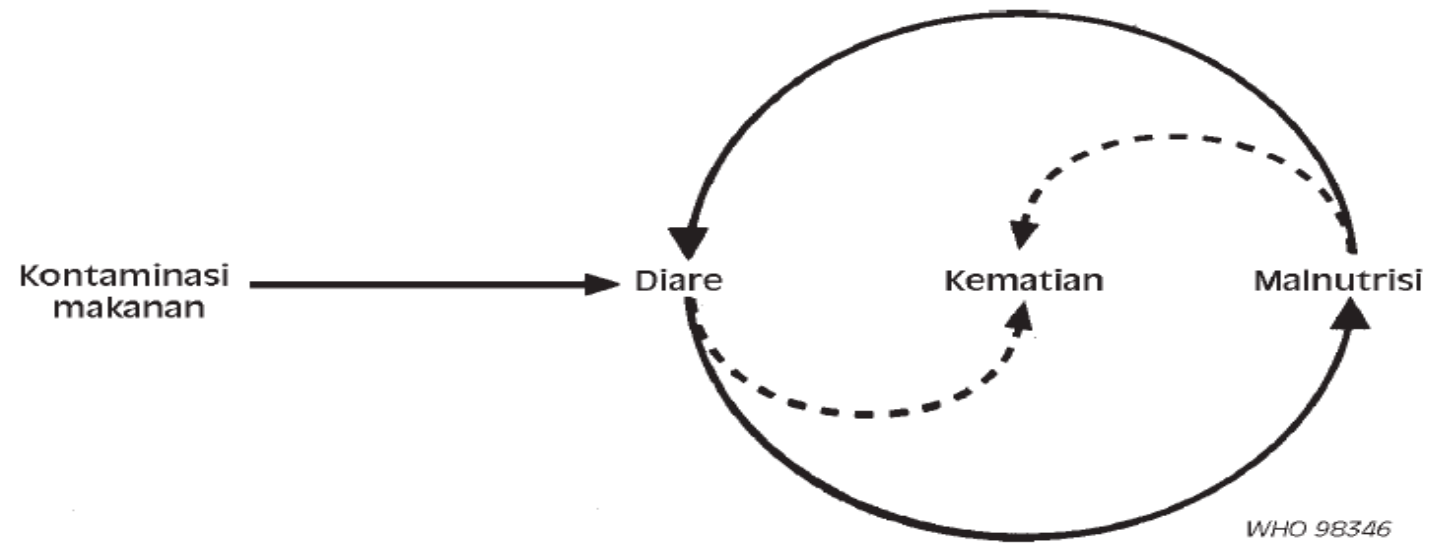

Gambar 3. Diare dan malnutrisi bergabung untuk membentuk sebuah siklus yang mengakibatkan penurunan status kesehatan dan kematian. 
Pasien dengan kekebalan tubuh yang baik dapat sembuh segera atau dalam waktu yang tidak lama, namun pada kelompok resiko tinggi seperti lansia, bayi, anak kecil, ibu hamil dan orang yang mengalami malnutrisi dan gangguan kekebalan, beberapa penyakit bawaan makanan dapat mengakibatkan kematian (Anonim 1, 2005). Hal tersebut digambarkan dalam diagram pada gambar 3.

\section{MEKANISME INFEKSI}

Setelah mengkonsumsi makanan atau minuman, ada selang waktu hingga terjadinya gejala yang disebut masa inkubasi. Masa inkubasi ini tergantung dari makanan yang telah terkontaminasi oleh agen biologis atau kimianya. Biasanya bahan kimia lebih cepat menimbulkan gejala umumnya kurang dari satu jam. Sedangkan bahan biologis tergantung jenis patogennya, bisa dalam selang waktu jam, hari ataupun minggu. Selama inkubasi, patogen tersebut melewati lambung, usus halus dan biasanya menempel pada dinding usus halus dan mulai memperbanyak sel. Beberapa patogen akan tetap di dinding sel tersebut, ada yang menghasilkan racun dan racunnya terserap pada aliran darah, dan beberapa patogen ada yang menginvasi beberapa jaringan yang lebih dalam lagi. Gejala yang timbul bervariasi. Beberapa patogen dapat menyebabkan gejala yang mirip, antara lain diare, kejang perut, dan mual. Banyak patogen memiliki kesamaan dalam gejala dan harus dibuktikan melalui uji laboratorium (Damayanti, 2008).

\section{MIKROORGANISME PENYEBAB FOODBORNE DISEASE}

\section{Campylobacter jejuni}

Kuman ini umumnya ada dalam saluran pencernaan hewan berdarah panas dan sering ada pada makanan yang berasal dari hewan karena terkontaminasi dengan kotoran hewan selama prosesing (pengolahan). Kuman ini menyebabkan gastroenteritis akut (infeksi pada saluran pencernaan) pada manusia. Gejala yang ditimbulkan antara lain diare, nyeri perut, demam, mual dan muntah. Sapi, babi, domba, kambing, ayam, kalkun, bebek, kucing dan anjing dianggap sebagai pembawa kuman ini, tetapi yang paling sering adalah unggas. Kejadian infeksi yang paling sering terjadi karena mengonsumsi makanan yang tidak dimasak, termasuk minum susu mentah yang tidak di-pasteurisasi.

Tindakan pencegahan dapat dilakukan dengan cara makanan asal unggas sebaiknya dimasak dengan baik dan menghindari kontaminasi silang. Misalkan pisau bekas memotong 
daging mentah sebaiknya dicuci bersih dahulu sebelum digunakan untuk memotong makanan yang matang (Dean, 1990).

\section{Yersinia enterolitica}

Sumber utama kuman ini terdapat pada babi yang terinfeksi (kuman ini hidup di daerah mulut dan saluran pencernaan babi). Biasanya anak-anak dan remaja peka terhadap penyakit ini. Kuman ini dapat berkembang biak pada suhu $0{ }^{\circ} \mathrm{C}$ sampai $44{ }^{\circ} \mathrm{C}$. Gejala yang ditimbulkan adalah nyeri perut, demam, diare, pusing dan muntah-muntah.

\section{Clostridium perfringens}

Gejala yang ditimbulkan adalah diare dan nyeri perut. Bakteri ini terdapat di saluran pencernaan karnivora (serigala, anjing), herbivora (tikus, gajah, kalkun) dan babi. Media penularan adalah daging babi dan kalkun. Makanan yang berasal dari hewan terkontaminasi oleh kuman ini karena daging terkontaminasi oleh kotoran atau isi saluran pencernaan di rumah potong hewan. Makanan yang sudah dimasak, dibiarkan dalam beberapa jam pada suhu kamar, disimpan dalam oven hangat atau disimpan dalam freezer dalam jumlah besar sehingga temperatur tidak terlalu dingin atau tidak cukup untuk mencegah pertumbuhan bakteri ini. Sehingga kasus penyakit ini dapat terjadi jika manusia mengonsumsi makanan masak yang sudah mengandung kuman. Tindakan pencegahan dapat dilakukan sebagai berikut. Makanan matang segera disimpan dan didinginkan dengan suhu dibawah $7{ }^{\circ} \mathrm{C}$. Jika ingin dimakan kembali harus dipanaskan dahulu pada suhu 71 - $100{ }^{\circ} \mathrm{C}$. Jika mungkin makanan segera dimakan setelah dimasak. Makanan sebaiknya dipanaskan diatas $60^{\circ} \mathrm{C}$ atau suhu yang lebih tinggi.

\section{Listeria monocytogenes}

Makanan sebagai media penularan kuman ini adalah sayuran coleslaw (semacam salad yang diberi mayonaise), susu yang dipasteurisasi, keju lunak, daging mentah, seafood, sayuran dan buah-buahan (makanan mentah). Gejala yang ditimbulkan sepsis (infeksi yang meluas ke dalam saluran darah), meningoencephalitis (infeksi di selaput otak dan di bagian otak), local infeksius (infeksi lokal, misalnya di kulit yg terkena, di saluran pencernaan yg

dilewati makanan tersebut), pregnancy infectious (infeksi kehamilan), granuloma infantiseptica (sepsis pada infant yang berbentuk granuloma). 
Virus

Biasanya penularan terjadi karena manusia mengkonsumsi makanan yang berasal dari hewan seperti daging sapi, domba, ayam, kalkun dan susu, dimana hewan sudah terinfeksi oleh virus tertentu. Virus yang dapat menyebabkan Foodborne disease ini dikenal virus yang tahan panas yang dapat ditularkan melalui susu sehingga tidakan pencegahannya adalah susu dipanaskan dengan di-pasteurisasi dalam waktu yang lama.

\section{Parasit}

Beberapa parasit ada dalam feses (kotoran) hewan dan dapat menyebabkan infeksi jika makanan yang tercemar oleh kotoran yang mengandung parasit termakan, dicerna dan diserap oleh tubuh. Sementara beberapa jenis yang lain terdapat dalam otot atau daging hewan (Dean, 1990).

\section{Toxoplasmosis oleh Toxoplasma gondii}

Kejadian toxoplasmosis pada manusia ini termasuk tinggi. Sumber utama penularan berasal dari kucing. Awalnya kucing memakan tikus atau burung yang mengandung Toxoplasma. Dalam tubuh kucing mikroorganisma ini hidup dan berkembangbiak menjadi bentuk yang infeksius bagi tubuh mannusia. Bentuk infeksius ini biasanya terdapat dalam kotoran kucing. Daging domba, babi dan mungkin sapi dapat terinfeksi oleh spesies ini dan menghasilkan kista (bersifat infeksius) yang dapat menginfeksi tubuh manusia. Terutama berbahaya pada wanita hamil. Jika wanita hamil terserang toxoplasmosis dapat berakibat keguguran, melahirkan bayi yang sudah meninggal, juga cacat bentuk dan kegagalan fungsi dari organ tubuh terutama yang melibatkan sistem syaraf pusat.

Penularan melalui daging dapat dicegah dengan makan daging yang benar- benar matang. Jika berkebun harus mencuci tangan dengan baik (menggunakan sabun) setelah berkebun. Pada wanita hamil sebaiknya menghindari tempat kotoran kucing. Bagi pemelihara kucing sebaiknya tempat kotoran kucing dibersihkan setiap hari.

\section{Trichinellosis oleh Trichinella spiralis}

Parasit ini berkembang biak dalam tubuh babi. Infeksi terjadi jika makan daging babi mentah atau setengah masak. Larva yang infeksius biasanya terdapat pada otot atau daging babi. Pada daerah yang penduduknya tidak makan daging atau tidak memperbolehkan makan 
daging babi, kejadian Trichinellosis sangat rendah. Gejala trichinellosis pada manusia adalah udema (pembengkakan) pada periorbital (bagian mata), demam dan sakit pada otot dan sendi (Dean, 1990).

\section{Taenia saginata}

Cacing ini hidup dan berkembang biak dalam tubuh sapi. Kejadian infeksi oleh cacing ini jarang tetapi sering terjadi di daerah dimana penduduknya sering makan daging sapi mentah. Tindakan pencegahan adalah pengontrolan yang ketat di rumah potong hewan, pembuangan kotoran manusia yang aman (tidak di sembarang tempat). Pemasakan daging yang baik atau jika daging dibekukan sebaiknya selama 5 hari pada suhu $-10{ }^{\circ} \mathrm{C}$.

\section{Cystiserkosis oleh Taenia solium}

Cacing ini hidup dan berkembang biak didalam tubuh babi. Infeksi dapat terjadi jika orang makan daging babi mentah atau yang dimasak setengah matang. Cacing ini dalam bentuk cysticerci dapat menyerang organ mata, jantung, otak, sumsum tulang belakang selain saluran pencernaan pada babi dan manusia.

\section{PERSONAL HIGIENE, PENGELOLAAN DAN PENYIMPANAN MAKANAN}

Telah diuraikan diatas bahwa kemungkinan manusia sebagai vector pembawa kuman sangat tinggi. Oleh sebab itu, seorang ibu sebagai pengelola makanan harus dalam keadaan tidak sakit seperti infeksi kulit, infeksi telinga, infeksi mata yang berat dan infeksi pernafasan berat serta menjaga personal higiene (Anonim 3, Tanpa tahun) seperti :

a. Mencuci tangan dengan air mengalir, menggunakan sabun cuci pada seluruh tangan, sela-sela jari dan ujung kuku kurang lebih 15-20 detik.

b. Mencuci bahan makanan yang hendak diolah hingga bersih.

c. Tidak meludah, bersin atau batuk di depan makanan

d. Selalu mencuci tangan setiap selesai dari kamar mandi, membuang samapah, memegang bahan mentah, membersihkan ingus, batuk, menggaruk rambut dan kegiatan lain yang memungkinkan kontaminan atau cemaran.

e. Memastikan peralatan yang digunakan untuk proses dan penyimpanan dalam kondisi bersih, tidak rusak dan tidak mengandung bahan berbahaya.

f. Memastikan tempat sampah dalam keadaan rapat atau tertutup dan jauh dari tempat pengelolaan dan penyimpanan makanan. 
Pengelolaan dan penyimpanan makanan yang tidak benar juga dapat menimbulkan kerusakan bahan dan kontaminasi makanan yang pada akhirnya dapat menyebabkan penyakit bawaan makanan (foodborne disease) (Anonim 3, Tanpa tahun). Dalam menyimpan bahan makanan, hal-hal yang harus diperhatikan adalah :

a. Jarak bahan makanan minimal $20 \mathrm{~cm}$ dari lantai, $10 \mathrm{~cm}$ dari dinding, dan $60 \mathrm{~cm}$ dari langit-langit.

b. Harus diatur rapi sesuai jenis dan karakteristik bahan, dengan susunan yang memungkinkan terjadinya sirkulasi udara yang baik.

c. Pada suhu yang tepat: bahan makanan beku $\left(-18{ }^{\circ} \mathrm{C}\right)$, bahan makanan dingin $(0-4$ $\left.{ }^{\circ} \mathrm{C}\right)$, serta sayur atau buah $\left(10-12{ }^{\circ} \mathrm{C}\right)$, serta suhu ruangan untuk bahan makanan kering.

d. Diberi label jenis, nama, serta tanggal awal penyimpanan.

Pengelolaan bahan baku makanan juga harus memperhatikan prinsip pencegahan kontaminasi. Misalnya, dengan memisahkan peralatan yang dipakai berdasarkan jenis (ikan, sayur, daging, buah) dan berdasarkan kondisi makanan (makanan mentah, makanan matang). Makanan yang telah matang disimpan pada suhu yang sesuai dan sebaiknya telah dikonsumsi sebelum 2 jam sejak makanan matang. Makanan juga disimpan pada wadah yang tertutup dan tidak terbuat dari bahan yang berbahaya bagi kesehatan.

\section{DAFTAR PUSTAKA}

Anonim 1. 2005. Penyakit Bawaan Makanan : Suatu Permasalahan Kesehatan dan Ekonomi Global. http:whqlibdoq.who.int/publications/2005/9794487074_chapter1_ind.pdf (diakses pada 14 Agustus 2010).

Anonim 2. 2005. Mengapa Pendidikan Kesehatan Diperlukan dalam keamanan Makanan?. http: http:whqlibdoq.who.int/publications/2005/9794487074_chapter2_ind.pdf (diakses pada 11 Agustus 2010).

Anonim 3. Tanpa Tahun. Tata Laksana Higiene Sanitasi untuk Penjamah Makanan. http: xa.yimg.com/kq/groups/11126306/2126254794/.../HSM_induction.pdf (diakses pada 14 Agustus 2010).

Bintoro, P. 2009. Pangan Antara Kebutuhan dan Ancaman. Semarang : Universitas Diponegoro Press. 
Bintoro, P; Nurwantoro; Sutaryo; Mulyani, S.; Rizqiati, H. dan Abduh, S. B. M. 2009. Pelatihan Keamanan Pangan dalam Keluarga Mewujudkan Keluarga yang sehat melalui makanan yang Aman, Sehat, Utuh dan Halal (ASUH). Semarang : Makalah disampaikan dalam Seminar Nasional Kebangkitan Peternakan.

Damayanti, Hernita Rini. drh. 2008. Mengenal Istilah Foodborne Disease. http:duniaveteriner.com/2010/01/mengenal_istilah_foodborne_disease/print (diakses pada 14 Agustus 2010).

Dean, Cliver O. 1990. Foodborne Disease. USA : University of Wisconsin.

Judarwanto, Widodo. Dr. SpA. 2009. Perilaku Makan Anak Sekolah. http:kesulitanmakan.bravehost.com (diakses pada 10 Agustus 2010).

Muassomah. 2009. Domestikasi Peran Suami dalam Keluarga. Dalam Jurnal Egalita. Vol. IV. No. 2.

NSW Multicultural Health Communication Service. 2004. Penyakit Bawaan Makanan (Foodborne Disease). Sydney : NSW Department of Health.

Shihab, Muhamad Quraish. 2002. Tafsir Al-mishbah, Pesan, Kesan dan Keserasian Alqur'an. Vol. 7. Jakarta : Lentera Hati. 